\title{
Measurement of longitudinal tibial nerve excursion during ankle joint dorsiflexion: an in- vivo investigation with ultrasound imaging
}

\author{
Matthew Carroll ${ }^{1,2^{*}}$, Janet Yau ${ }^{2}$, Keith Rome ${ }^{1,2}$, Wayne Hing ${ }^{1,3}$ \\ From 3rd Congress of the International Foot and Ankle Biomechanics Community \\ Sydney, Australia. 11-13 April 2012
}

\section{Background}

A key mechanical function of peripheral nerves is their ability to slide in relation to the surrounding tissues. This function is of paramount importance to maintain ideal neural function [1]. Advances in ultrasound imaging and the development of specific software (crosscorrelation analysis) have made it possible to analyse real-time ultrasound images, allowing for quantification of in-vivo peripheral nerve movement [2]. Cross-correlation analysis has been utilised in numerous upper extremity in-vivo neural investigations [3-5]. No study has investigated in-vivo longitudinal nerve excursion at the ankle joint. The aims of this study were to quantify the degree of longitudinal tibial nerve excursion as the ankle moved from dorsiflexion to plantarflexion and assess the between session intra-rater reliability of the ultrasound imaging technique.

\section{Materials and methods}

A sample of sixteen participants (10 male, 6 female; mean [SD] age 34.7 [9.3] years old) were recruited. A three second video loop of the tibial nerve was captured by ultrasound imaging as the ankle moved from $20^{\circ}$ plantarflexion to $10^{\circ}$ dorsiflexion. The tibial nerve was imaged on two occasions with a 5 minute interval between measurement sessions. Foot and ankle position was standardised on a measurement platform. Video loops were analysed to determine the degree of longitudinal nerve excursion. Intraclass correlation coefficients (ICC), with 95\% confidence intervals (CI), standard error of the measurement (SEM) and the smallest real

\footnotetext{
* Correspondence: matthew.carroll@aut.ac.nz

'Health and Rehabilitation Research Institute, AUT University, Auckland, 0627, New Zealand

Full list of author information is available at the end of the article
}

difference (SRD) were calculated as an indication of reliability and measurement error.

\section{Results}

Results demonstrated mean [SD] longitudinal excursion of 3.01 [0.97] $\mathrm{mm}$. The between session intra-rater reliability was excellent (ICC $=0.93$; 95\% CI, 0.70-0.96), with SEM, $0.26 \mathrm{~mm}$ and a mean SRD of $0.75 \mathrm{~mm}$.

\section{Conclusions}

Ultrasound imaging in conjunction with cross correlation analysis presents a reliable technique to quantify invivo tibial nerve movement during ankle joint dorsiflexion.

\section{Author details}

${ }^{1}$ Health and Rehabilitation Research Institute, AUT University, Auckland, 0627, New Zealand. 'Department of Podiatry, AUT University, Auckland, 0627, New Zealand. ${ }^{3}$ Department of Physiotherapy, AUT University, Auckland, 0627, New Zealand.

Published: 10 April 2012

References

1. Shacklock M: Clinical Neurodynamics: A new system of musculoskeletal treatment. Edingburgh: Elsevier; 2005.

2. Dilley $A$, et al: The use of cross-sectional analysis between highfrequency ultrasound images to measure longitudinal median nerve movement. Ultrasound Med Biol 2001, 27:1211-1218.

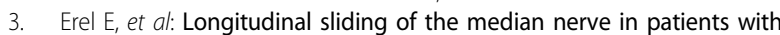
carpal tunnel syndrome. J Hand Surg Br 2003, 28:439-443.

4. Dilley $A$, et al: Quantitative in vivo studies of median nerve sliding in response to wrist, elbow, shoulder and neck movements. Clin Biomech (Bristol, Avon) 2003, 18:899-907.

5. Dilley A, Summerhayes C, Lynn B: An in vivo investigation of ulnar nerve sliding during upper limb movements. Clin Biomech (Bristol, Avon) 2007, 22:774-779.
(C) 2012 Carroll et al; licensee BioMed Central Ltd. This is an Open Access article distributed under the terms of the Creative Commons Attribution License (http://creativecommons.org/licenses/by/2.0), which permits unrestricted use, distribution, and reproduction in any medium, provided the original work is properly cited. 
doi:10.1186/1757-1146-5-S1-037

Cite this article as: Carroll et al:: Measurement of longitudinal tibial nerve excursion during ankle joint dorsiflexion: an in-vivo investigation with ultrasound imaging. Journal of Foot and Ankle Research 2012 5(Suppl 1):037.

Submit your next manuscript to BioMed Central and take full advantage of:

- Convenient online submission

- Thorough peer review

- No space constraints or color figure charges

- Immediate publication on acceptance

- Inclusion in PubMed, CAS, Scopus and Google Scholar

- Research which is freely available for redistribution

Submit your manuscript at www.biomedcentral.com/submit 